\title{
Why Brownlee Left
}

Although Muldoon relishes 'the rhyme on "Aristotle" and "bottle"' in Byron's epic Don Juan, he still claims 'Beppo' as 'my own favourite.' His savouring of the palatable and alphabetic rhyme, his unconventional preference (in canonical terms) for Byron and his idiosyncratic choice of 'Beppo' are indicative of the rhyming panache and the canonical negotiations of his own language and poetry. Muldoon's identification with Byron indicates other similarities and signals an, as yet, unexplored framework for his own poetic priorities. Both Byron and Muldoon write of solemn concerns in irreverent form and they adopt radical attitudes while maintaining allegiances to traditional form. Furthermore, Byron's peregrinations, both in literature and life, posit a very viable template for Muldoon's language and concerns in Why Brownlee Left, which overlap, develop and differ from Mules.

In Mules, language contains its own alterity and continuously transforms its own conditions and consequences in a double take on the reality it both acknowledges and distances itself from. Bestiality of many sorts, eroticism too, not least linguistic, paronomasia, ekphrastic oscillations and a mulish resistance to ordinary directives and orders of language weld and wrench new meanings in this volume. Such intransigent and intransitive language seems pertinent to a condition that does not yield itself easily to representation of any kind - linguistic, musical or visual - a condition which Muldoon's poetic language refracts and refigures as much as it represents. Whereas Mules imagines hybrid identities and mixed cultures, and tends to release the spontaneous as well as the sterile of compressed spaces, whether these are considered to be geographical, traditional, political, poetic or linguistic, or a composite of these, Why Brownlee Left seems to reflect upon the complexities of origin, ancestry and identity, and to explore the terrains of exit, emigration and effacement. Evidently, these two clusters of themes are connected in terms of time, place and self and the whole volume traces these interrelations. In fact, the notions of trace and tracing inform the volume. Tracing, a comprehensive search for evidence, addresses adroitly the mystery the title (Why Brwonlee Left) articulates, but also has much wider implications. The act of pursuing non-material dimensions of an event that seems to be lost but which still bears upon the past and the present and the future, brings into question the understanding of

1 Paul Muldoon, ed. The Essential Byron (New York: Ecco Press, 1989), 5. 
such terms as origin and identity, emigration and becoming. ${ }^{2}$ These themes are explored in a language that defines and deflects these very themes, but which is also shaped and modulated by them.

A language that incessantly traces itself, adlinguisticism, alters constantly, not only the questions themselves and their potential answers and solutions, but the very conditions under which these questions and answers might be arrived at. Just as a sign is a unity of heterogeneity and distemporalities - the signifier is not the signified, the signifier assumes and resumes its fleeting identities by contrast to other signifiers - and just as language hovers on the brink of itself and that to which it might refer, ideas of origin, identity and becoming cannot be constituted except reciprocally with non-identities and non-origins; their own traces which transform and engender new possibilities. A differing, deferring and modulating language is not merely a contrived linguistic imposition upon wholesome ideas of ancestry and extraction, homogeneity and belonging, it brings forth new implications for these ideas not previously considered. Such conditioning of the concepts of origin, identity and becoming generates alternative histories and futures, other identifications and other alternatives. Muldoon understands well this sense of the trace as not an alternative to origin and identity, a non-origin or separate other, but as constituent of the originary and identarian, and that the trace relates as much to the future as to the past:

One of the ways in which we are most ourselves is that we imagine ourselves to be going somewhere else. It's important to most societies to have the notion of something out there to which they belong, that our

2 A direction from past to future is imbricated in many of the discourses that have been dominant in Ireland, for example the movement from genesis to revelation in religious discourses and from history to revolution in radical ones, but in most of these, temporal divisions are exact. That the Irish are prisoners of their own past waiting in vain for release is a cliché in poetic imagination that runs at least from the onset of Christianity via the poets of the dispossessed and the retrospective aspects of the Revival to the atavism of Heaney's North. Frank O'Connor discusses the heart of this matter in The Backward Look (Basingstoke: Macmillan, 1967). Perforce, the focus on future has existed as a countervailing discourse. The future of Irish literature, and by implication the nation and not least his own destiny, is prevalent in Thoams MacDonagh's Literature in Ireland, and calibrated in his declaration that 'The futurists may be charlatans, or fools, or lunatics. They may be prophets.' Literature in Ireland (Tyone: Relay Books, [1916] 1996), 3. 'The Irish are futurologists of necessity,' Declan Kiberd avers in 'Anglo-Irish Attitudes' in Deane et al., Ireland's Field Day, 95. For the unfolding of a future for an Irish nation incessantly traced and tracing, see Graham, Deconstructing Ireland. 
home is somewhere else ... there's another dimension, something around us and beyond us, which is our inheritance. ${ }^{3}$

Why Brownlee Left, as the title indicates, reports on a special case, a disappearance, an absence, the possibility of appearing somewhere else; a double sense of self, place and time that was there from the start. This mystery leaves a hermeneutic vacuum to be filled with meaning, a void to be lamented or welcomed. Only traces remain of Brownlee in the title poem, which is centrally placed as number fourteen of twenty-seven poems in a series that is redoubled by the final recursive journey, 'Immram.' Absence appears at the centre of the volume, an absence in which Brownlee is traceable, a disappearance which allows for his many metamorphoses throughout the verses.

The volume investigates the reasons for departure - Why Brownlee Left many of which are also adumbrated in previous volumes, with questions of who, when, where and how waiting in the wings, in a poetic language that cannot be easily aligned with ideas of rootedness and unitary selfhood. All the possible departures and arrivals in the volume recall epic journeys, Homeric and Gaelic. All the questions surrounding Brownlee recall an Oedipal quest for identity and destiny. Just as Oedipus's fate is prefigured by his name and fulfilled by the stratagems to evade his predestined fate, Brownlee, as many other characters in the volume, is ultimately ensnared by forces of which he is unaware, or conditions he assumes he has escaped. In this unresolved case, language not only relates the mystery; the mystery tends to reflect upon the inscrutable course of linguistic action. Why Brownlee Left conducts imaginative and inconceivable interrogation into ideas of origin and identity, departures and arrivals, chronology and narrativity, and into the mysteries of language. An astonishing ability to unthink essential concepts and crucial events of the human condition dominates the poems, and their language. This volume and these verses present alterratives, the integral aspects of alterity in multiple modes of narrative, a number of alter egos in formative processes of self, and versions of unrealised pasts and potential futures.

Muldoon's third volume traces several previous concerns in his poetry. 'Like the last of an endangered species' (8) the final line of the opening 'Whim' states of the interlocked love-making couple in the Botanic Gardens of Belfast and 'The Boundary Commission' records the stasis of a narrowing horizon: 'He stood there, for ages, / To wonder which side, if any, he should be on' (15). The lines are replete with the menace of extinction and the numerous states of inbetweennness that loom large in Muldoon's first two volumes, also with an

3 Haffenden, Viewpoints, 141. 
acute intuitive sense of the vagaries of experimental poetic language. The volume's title also reflects these threats and divisions: did Brownlee leave by his own will? Why? Who was he? When did he leave? Where has he gone? For good? Will he come back? Was he forced to go? By whom? Why? Is he still alive? What has happened? What will happen now? Questions of this kind have an obvious existential quality to them, but they touch a raw nerve in a society of high emigration and a frighteningly high rate of unexplained disappearances, such as was the situation in Northern Ireland during the Troubles. The title certainly suggests an inquiry - psychological, sociological, demographic or judicial - into the truths and falsehoods of a specific subject, possibly against the allegations, inference and slander launched by other parties. The title's reportorial matter-of-factness contains uncertainties too, as the interrogative pronoun upsets the affirmative statement from the very beginning. Furthermore, the alternative contexts of the initial pronouncement are uncertain and range from individual viewpoint or judgment, news headlines, specific case studies in surveys of demographic change and other kinds of formal documents or public debates. The position of the statement at the crux of several actual scenarios and a multidiscursive undecidability suggests that whenever the idea of truth becomes multivalent and perspectival, this is not, as is often claimed by detractors of deconstruction, only a result of language manipulation. Notions of truth subsist between their own ideality and the actualities of life. Any metaphysical idea of truth transports the concept beyond its empirical and ontological actuality; truth based upon the life of the living present enters the problems of relativity. Truth is neither substance, nor essence, and hardly ever present as such; it is frequently obscure, partial and transient, and often takes the form of arbitration, conflict, compromise and consensus. In this respect, the language of Muldoon's third volume questions many uncontested notions that have established themselves but which deserve closer scrutiny.

Why Brownlee Left, an aetiology of disappearance, traces the impact of metaphysics, history, social conditions and mental states upon individual decision. 'That's Ireland, anyways. There's always someone leaving,' Maureen states in Martin McDonagh's The Beauty Queen of Leenane. ${ }^{4}$ Perhaps at no time since the First World War has this sense of departure and the decision to remain been more heartfelt than in Northern Ireland in the late 1970s, when the conflict stagnated into deadlock and produced a strong wish on the part of many inhabitants to leave behind tragic events of a personal, tribal and communal nature in an environment that appeared to hold no future. Muldoon does not

4 Martin McDonagh, The Beauty Queen of Leenane (London: Methuen, 1996), 21. 
exempt himself from this mood; the volume posits another correlative, perhaps slightly less subjective than previous ones. A total of twenty-eight poems in the book, the number of twenty-nine lines in the opening poem, 'Whim,' and the sum of thirty stanzas in the final climax, 'Immram,' figure the age of the author at the time of the poems' composition and publication. The numerological signature inscribes his personal life span upon the many dimensions of the book. Meanderings in the mystery of language ensure the creative Muldonic signature.

'Why Brownlee Left,' the volume's title poem, is central to the volume in many ways. Its verses assemble and distribute the answers and questions to the mysterious disappearance of Brownlee: 'Why Brownlee left, and where he went, / Is a mystery even now' (22). Why Brownlee Left attends to departures, arrivals and journeys as reigning tropes of the book and these tropes pit individual existence against the questions of origin, freedom and fate in a manner that tends to problematise these very concepts. Alterratives abound. Centrally placed as the pivotal point of the book, the title poem divides the twenty-eight poems in two halves. It is both preceded and succeeded by thirteen poems; the long, final finish, 'Immram,' enacts a powerful doubling of them all. Although the two halves of the book intersect and are linked, the first sequence tends to sketch situations and events that all impart incentives for leaving; the second section tends to enact departures of various kinds. In this temporal scale, the moment of Brownlee's disappearance moves beyond, as the enjambment of the final verse illustrates, past possibilities and future alternatives. The poem also renders the significance of the single letter and the poetic specifics of language as major concerns of the volume.

That so many words associated with the quest for understanding - why, who, when, where, what - or the processes of rendering meaning in alphabetic form - word, write, writhe, wring, warp, weave, wend, wiggle, waggle, wrestle, wreak, wreathe and wrench - involve the letter w might be coincidental. Nevertheless, its mere visuality evokes prolonged twining and twinning and its phonetic variables are intricate. The 23rd letter of the modern English alphabet is an addition to the ancient Roman alphabet which originates from a ligatured doubling of the Roman letter represented by the $\mathrm{U}$ and $\mathrm{V}$ of modern alphabets. The ordinary sign for the phoneme $[w]$ was at first a double $u, u u$, which was superseded by a character from the Runic alphabet, $\mathrm{W}$, and it has never lost its original name of 'double U.' Interrogatives, split etymologies and the doubling of semi-identical letters capture with alphabetic inscription the mystery of Brownlee's personality, background and disappearance. The twinning and twining of the alphabet's well-wrought ws in the name and verses spell out Brownlee's dilemmas. The ten ws of these verses, especially the five 
ws of the two first lines, impose a compelling sense of overlapping dualities to the protagonist's psychology and to his historical roots, social situation and disappearance, and to his transition between the past and the future as well as in the poetic presentation thereof. Just as the w has ceased to be pronounced in a few words, for example write, answer, sword and two, the letter actually documents something which has disappeared. Has Brownlee been squeezed out of existence or made invisable by double pressure or liberated by dual possibilities?

Brownlee is confined, perhaps even defined, within the strict horizons of his rural environment. An estimate of human happiness in an itemised list of agricultural products - two acres of barley, / One of potatoes, four bullocks / A milker, a slated farmhouse - circumscribes horizons, and threatens to asphyxiate individual aspirations and the instant fame of Brownlee's disappearance reveals the exceptional nature of the event. At the start of a new day, at the back end of a bad season, somewhere between two stanzas, the main character vanishes in the poem's volta, an 'ambiguous, unwittingly existential gesture' in the words of Alan Jenkins. ${ }^{5} \mathrm{His}$ escape is also measured in the octave's quick departure from the standard foot and meter. Similarly, the sestet does not bring forth the form's conventional resolution. Where the lineal syntax and rhyme pattern of the first verses hold some sense of fixity, the latter ones move with uncertainty in enjambment and aural resonances that tend to depart from their own sounds: 'with' and 'wife'; 'famous,' 'foot to,' 'future.' Anthropomorphic horses project a lack of marital union in Brownlee's life, and capture a sense of restless stasis, while on the page, they transcend elegantly in the enjambment 'black / Horses' the confines of verse and time, and stare into the future into which Brownlee might have transported himself.

The alphabetic amalgamation so central to Brownlee's name and the many departures and equivocations of these verses suggest the absence of single solutions to his mystery. Alan Jenkins interprets Brownlee as 'a farmer who uproots himself, leaving his smallholding,' and the poem as 'resonant with both blazing self-assertion and utter blankness.' ${ }^{6}$ Derek Mahon also takes this view of Brownlee as a fictional representative of the not uncommon event when a bachelor farmer 'simply walks out of his house, and takes a ship to America, without a word to a soul; he goes lightly, unencumbered by regret or personal possessions, and is never heard of again. ${ }^{7}$ Tim Kendall and Clair Wills take

5 Alan Jenkins, 'The Art of Gentleness,' Times Literary Supplement, 14 November 1980, 1287.

6 Ibid.

7 Derek Mahon, 'Long Goodbye', London Review of Books, 20 November - 4 December 1980, 6-7. 
their interpretation from Muldoon who declares: 'Brownlee suggests a brown meadow, a ploughed field, and so - in a strange sort of way - his end is in his name, he's fulfilled his purpose even before he begins.' ${ }^{8}$ Brownlee might have emigrated to forge a new future in America, England or elsewhere or he might have been smothered by his own craft and tradition, as a recent avatar of Patrick Maguire in Patrick Kavanagh's enactment of sterile farm life in 'The Great Hunger.' The removal of a $w$ in the text, a false clue, an ostentatious visual marker of something disappeared, confirms where he has gone: ' $t(w) o$ acres of barley.' However, the poem is not necessarily a singular keystone in the volume since these two options coincide with one another: the choice of departure often ends in stasis and the choice of staying results in other forms of departure throughout the texts.

'Why Brownlee Left' is closely connected to the preceding 'Anseo' and the succeeding 'Immrama' by thematic links, textual proximity and formal features. Like poetic clauses in the volume's syntax, these variegated sonnets combine and contrast each other. Bownlee's unresolved destinies and disappearance reflect the static confinment's fulfillment of the former and the disappointment of departure of the latter. Conversely: does the IRA Commandant of 'Anseo', in a menacing way, have anything to do with Brownlee's disappearance? Does Brownlee reappear in 'Immrama' as the Nazi on the verandah in Brazil, or as the son trailing his spirit? Or as the persona in 'an hotel room in New York City' in 'Quoof' in the next collection? Or the many other silenced or mobile characters throughout subsequent volumes? Does the Gaelic language in the title of the two first poems insinuate a constriction from which Brownlee liberates himself, or does it indicate the impossibility of self-realisation in a life and culture that has largely been deprived of its natural language? Questions accumulate in the poem and in the book and the answers are confused, as are the ideas of origin, identity and language. In theme, form and language 'Why Brownlee Left' assembles and disassembles many of the volume's underlying currents.

'I use names perhaps far too often in a Johnsonian, emblematic way,' Muldoon concedes, and tips his hat to Heaney's critique of this mode in Mules, but of his many emblematic names in this volume - Will Hunter, Bran, Golightly, Billy Wetherall, Joseph Mary Plunkett Ward - Brownlee, as well as Coulter and Foster, sounds less obtrusive and better grounded. ${ }^{9}$ In colour and declension, the name, almost a pronominal shirt of Nessus, echoes the darker doctrines of

8 Haffenden, Viewpoints, 140; Kendall, Paul Muldoon, 68-69; Wills, Reading Paul Muldoon, $77-78$.

9 Haffenden, Viewpoints, 140; Heaney, Preoccupations, 213. 
'blut und boden,' and the dissemination in Ireland of a mixed legacy of German ideology, history and culture, one also heard in other poems such as 'Early Warning, 'Ireland, 'Anseo,' 'Immrama, 'Truce' and 'The Princess and the Pea.'10 Brownlee's involvement with cultivating the land and his possible fates also resonate with the agriculture of 'Early Warning' and 'Lull,' the expatriation of 'Immrama' and 'Promises, Promises,' the territorial conquest of 'Truce,' and the horrific decomposition and entombment in 'The Princess and the Pea,' 'Grief' and 'Come into My Parlour.' 'Why Brownlee Left' is also a poem about poetry, and about linguistic complexities.

Agricultural activity has functioned as an image of poetic creativity from Hesiod's Works and Days via Romantic organicism to different strands of contemporary poetry. 'Why Brownlee Left' ambivalently evokes this tradition. The poem plays on the Latin versus, the double meaning of ploughing the furrow in a field of rural cultivation and poetic creation, and on the almost identical phonetics of versus and verses. Their abbreviations as v. and v. also meet in the poem's significant w. Semi-stopped, fully-stopped, run-on lines and the volta enact a register of departures, transitions and arrivals. The ambiguity of Brownlee's fate, whether he bolts from or is buried in his plot, suggests Muldoon's own double bind in relation to organicist poetics - for example his novel readings of Frost, his productive resistance to parts of Heaney's chthonic groundedness, his ambiguous deployment of and many departures from this poetic idiom in his own poems, and his preference for Byron among the Romantics. ${ }^{11}$

Byron's poetry emerges as an interesting and scarcely discussed source of inspiration for Muldoon's poetry during this period. In his introduction to The Essential Byron, Muldoon argues:

10 Links with German history go back to the Celtic age, but became a more sensitive point in Ireland and Northern Ireland at least after Irish neutrality during the Second World War and De Valera's condolence on the death of Hitler. Aspects of Lutheran beliefs and fascist doctrine are easily traced in the ideologies of Loyalist and Republican organisations. Muldoon foregrounds the dilemmas of 'race-consciousness,' 'racial blood-music' and 'pure poetry' in the dispute between Louis MacNeice and Kevin Higgins in the enigmatic prologue to his edition of The Faber Book of Contemporary Irish Poetry (London: Faber and Faber, 1986), 17-18.

11 In his comments on Frost's poetry Muldoon continuously attends to the linguistic aspects of the American Laureate's poetry, 'his apparently simple, almost naïve, tone of voice and use of language, under which all kinds of complex things are happening,' 'his mischievous, sly multi-layered quality under the surface' and the 'undercutting of what he seems to be saying.' Haffenden, Viewpoints, 134; Michael Donaghy, 'A Conversation with Paul Muldoon,' Chicago Review 35, no. 1 (1985), 84. Muldoon includes many of Heaney's organicist poems in his Faber Book of Contemporary Irish Poetry, but none of his bog poems. 
Byron's mature style is wonderfully discursive, ranging from Aristotle through hitting the sack to hitting the bottle sack, while relishing the rhyme on 'Aristotle' and 'bottle' along the way; he reminds us again and again that poetry can be serious without being solemn, that it might even be fun. ${ }^{12}$

Byron's poetry prevails as a presiding spirit over Why Brownlee Left. The major reason for this is Byron's many departures, arrivals and circumambulations, and his sensitivity to language and his relishing of humour, pun, rhyme and pleasure. The Romantic renegade's propensity for eccentric rhymes - 'ragouts / stews,' 'Improvisatori / also tell a story,' 'Cicisbeo / Cortejo / Po to Teiro,' and 'polacca / tobacco' which could easily be added to Muldoon's example of 'Aristotle / bottle' - remains a tuning fork for Muldoon's own saucy sounds and macaronic coinages. Byron's susceptibility to narrative also parallels Muldoon's knack for alterrative. ${ }^{13}$ Furthermore, Muldoon's choice of Byron over the other Romantics indicates a preference for a transitional figure of neoclassical wit and irony over the profuse emotionalism and revolutionary poetics of his Romantic contemporaries. Byron's pro patria partitions, expatriate wanderings, erotic nerve, poetic pugilism and submersion in continental classicism are all attractive features to Muldoon which leave their imprint on Why Brownlee Left. His choice of including 'Beppo' in toto in his edition of Byron tightens the links:

I wanted to avoid as much as possible the chopping up of poems into kindling, but could not (as with 'Don Juan') manage it entirely. On the other hand, my choice of a complete, longer poem like 'Beppo' over, say 'The Siege of Corinth' may strike some readers as being whimsical. That, I'm afraid, is a risk I have to take. ${ }^{14}$

'Don Juan,' obviously, needs to be chopped due to its length; Muldoon's other preferences here indicate a prioritisation of linguistic insouciance and personal affairs over historical events and political matters. Attitudinal identifications between Byron and 'Beppo' probably extend to Muldoon's own subjective correlatives. As an adventurous romance steeped in cultural reference and replete

\footnotetext{
12 Muldoon, The Essential Byron, 5.

13 For Byron's adventures and his European importance, see, for example: Hippolyte Taine, The History of English Literature, trans. H. Van Laun, 4 vols. (London: Chatto and Windus, [1863-1867] 1897), vol 4, 1-70; Bertrand Russell, The History of Western Philosophy (London: Routledge, [1941] 1996), 651-66o, 716-722. George Gordon Byron, The Poetical Works of Lord Byron (Oxford: Oxford University Press, 1904), 625-634.

Muldoon, The Essential Byron, 5.
} 
with dramatic dialogues and auto-narrational comments, 'Beppo' suggests an interesting counterpoint to the poems in Why Brownlee Left, not least to the romantic encounter in the opening 'Whim,' and to the outlandish escapades in the final 'Immram.'

Did Brownlee leave on a whim? Perhaps he did. 'Whim,' the first poem of the collection, does not discount the possibility. Muldoon defends sudden and seemingly unmotivated impulse as an artistic prerogative in his choice of 'Beppo' (and perhaps Byron too) and in Literature in Ireland Thomas MacDonagh argues that 'whimsicality is an Irish characteristic as definite as any.'15 Byronic impetuosity and Gaelic culture co-exist in 'Whim,' which is decked out with amorous caprice and love of Celtic lore by way of idiomatic conversation and grim ironies. A casual dialogue in 'the Europa Hotel' on the manuscripts and translators of the myth of $\mathrm{Cu}$ Chulainn - the Hound of Ulster - leads to a somewhat steamy fling in 'the Botanic Gardens':

To cut not a very long story short, Once he got stuck into her he got stuck Full stop.

They lay there quietly until dusk

When an attendant found them out.

He called an ambulance, and gently but firmly

They were manhandled on a stretcher

Like the last of an endangered species. (8)

Perhaps the first poem ever on human dog-knitting, this canine temper of human desire in the horticultural conservatory unleashes linguistic deviations and infidelities, as much as natural and erotic ones. The copulation sweats with the cross-fertilisation of many sorts beyond the beastly and the human: the Gaelic and the English, the old and the new, the conventional and the creative. The title word is indicative of Romantic spontaneity and Irish character and the poem implies a renewal of the Hiberno-English language tradition. In the verses, this is represented by Kuno Meyer's and Standish O'Grady's translations of the $\mathrm{Cu}$ Chulainn myth - and how new generations take over from older. But the image of natural regeneration does not correspond totally to cultural activity: the speaker in the poem prefers Meyer's older translation to Grady's newer. Lineation, lexical choice and sounds are also subject to risky copulation and regeneration. The graphic line stop cuts short the flow of verse as much as the protagonists' ecstatic intercourse and assonantal gradation and

15 MacDonagh, Literature in Ireland, 8. 
sibilant sounds in the masculine end words take over for rhyme harmony. The aftermath is finally rendered in deibhidhe sound patterns, passive tense and a vocabulary of casualty and immanent death. Conversely, the poem inseminates the cliché of 'the Europa Hotel' in Belfast as the 'most-bombed hotel in the world' with the normal life of drinking, intellectual debate and flirtation. This poetic counter-cliché and the poem's enactment of poetic and linguistic transformation anticipate in the imaginative realm the reconstruction and the revivification the hotel experienced after the ceasefire - a presentiment in poetic artifice of actual progress in architecture and social life that also characterises the many other poems in the volume that depict and depart from the sites of Belfast: 'The One Desire,' which describes the derelict palm-house in the Botanic Gardens that has since been renovated, and 'The Weepies' and 'History.' Furthermore, the display of bodily acts in 'Whim,' doggy-style in a public place, heated and comfortless, also evokes the classical cynicism of Diogenes the dog, and anticipates the linguistic dog-nailing and philosophical opprobrium in, for example,' Madoc' (Mad, 13-261) and 'A Collegelands Catechism' (MSG, 15). Exhausted and helplessly intertwined, the couple recalls the vulnerability of the hedgehog and the many mule motifs of the previous collections as their uncertain end reflects upon the fate of human and aesthetic and linguistic whims. Unions of larger proportions are also encapsulated in this deadlock. However, cultural cross-fertilisation, formal regeneration and linguistic dissemination have proven vital to the durability of Muldoon's poetic language. Muldoon's language in 'Whim,' as Byron's in 'Beppo,' suits the caprice of the couple, bears upon the mystery of Brownlee and is suffused with the contradictoriness of Belfast at the time.

'October 1950,' just like 'Whim,' presents another alterrative. 'Whim' offers startling alternatives of human language and intercourse. 'October 1950,' a date which most likely marks the conception of the author himself, meditates on the chanciness of procreation, life and language. Certainly a poem on origins, whether those of Muldoon's, Brownlee's or anybody else's, or those of the poem itself and of language, these verses thwart the expected ordinary course of such a quest. The moment of conception cannot be fixed and yields no elucidations, it merely exists as another point of obfuscation and randomness to questions of origin and identity. The poem ends:

Whatever it is, it goes back to this night,

To a chance remark

In a room at the top of the stairs;

To an open field, as like as not, 
Under the little stars.

Whatever it is, it leaves me in the dark. (9)

Uncertainties about the alternative places of conception situate the coming into being between the mundane and the divine in a similar manner to 'Mules.' Conceived in the confines of prosaic domesticity or resulting from a more romantic outdoor liaison, any metaphysical governance, in the form of celestial stars, is deprived of illuminating influence. Questions of birth, identity and fate depend as much on chance and contingency as plan and providence. Part of the poem's boldness is contained in the separation of identity formation from divine design, national paradigms and parental aspirations. Most ostentatiously, such a vision points to a detachment from the directives of religion, country and family, but as these defining factors are already rendered precarious, the individual life becomes an emergent process in which the premises of choice are not always clear. Thus, each decision in life can confirm as well as oppose the formative influences that weigh upon the individual, a permanent state of uncertainty that in itself calls for careful consideration rather than conviction and foreclosure. This copulative stage, before and beyond conception, a possible pre-individual event of formative significance, is resonant with moments of waste or potential life - 'unremembering darkness, an unsteady hold,' as the next poem states (10). But this poem on the haphazardness of origins also activates its own precarious literary genealogy and poses questions of linguistic derivation.

Whatever it is, it all comes down to this;

My father's cock

Between my mother's thighs.

Might he have forgotten to wind the clock? (9)

A truly corporeal moment of conception, these explicit lines are denuded of the shocking contraceptive delight, fear of censure and envy of Larkin's 'High Windows' and the clock-allusion to Sterne's Tristram Shandy implicates the procreative moment in endless lines of familial ancestry and in the complexities of narration of that eighteenth-century novel. The arbitrary question speculates on the timing of sex and daily duties, and refers to the fate of Michael O'Rahilly and Yeats's celebratory poem: "Because I helped to wind the clock / I come to hear it strike."16 Leaving his wife and three children behind as the only

16 Yeats, Collected Poems, 354. 
leader of the Easter 1916 Rebellion to die in action, O'Rahilly felt honour-bound to participate in the rising he supported, but whose timing he opposed. Muldoon's line harbours the possibility of not being conceived in October 1950, or at all, if his father had been otherwise engaged at the time, or dedicated to political action. The verses, thus, imagine the non-birth of the persona, not merely the alternative directions his life might have taken.

Parentage, biological and literary, appears capricious and at the mercy of chance in 'October 1950;' the poem also hints at an alternative existence, even non-existence. Thus, it implies Muldoon's way with language, too. Etymological quest, so important to dinnseanchas for example, frequently bears less importance to Muldoon's poetic language than the routes of false or fanciful etymologies, the lines of linguistic licence, the fields of phonetic fantasy and the seas of semiosis - 'anything wild and wonderful' (9) as the poem runs. Such a farewell to the roots and restrictions of language in this poem and in the many departures in Why Brownlee Left indubitably announces the arrival of the yet unconceived and possibly non-existent life of the language to come in Quoof, the next volume, and the subsequent Madoc, Annals of Chile and Hay. 'October 1950' bristles, hedgehoglike, in theme, intertextuality and language with alternatives to conventional ideas of birth and beginnings, of literature and the poetic and of narrativity and happenstance.

If conception, birth and life are as much tied up with metaphysical mysteries as biological acts, the origins and functions of language are often predicated upon the transcendent. Religious directives manifest one such transcendent value. 'The Bishop' deals with the dilemmas of submitting to or absconding from such discourses. With premonitions of Brownlee's disappearance and of the godfather's quasi-absolution in the concluding 'Immram,' a priest's last minute decision to renege on his vocation uncannily fulfills his vocation:

The night before he was to be ordained

He packed a shirt and a safety razor

And started out for the middle of nowhere,

Back to the back of beyond,

Where all was forgiven and forgotten,

Or forgotten for a time. (14)

The clergyman absconds and exchanges the spiritual realm of sanctity and piety for an abstract and intangible place. Unloosening tetrameters and unrhymed sentences signal shifts from certainty to flux and the quotidian 
paraphernalia conceal a menacing edge. The clichés also convey a lapse into the sublapsarian; the word is made colloquial. Family, friendship and prosperity fill the ecclesiastic's new life until a second peripeteia occurs:

\section{His favourite grand-daughter}

Would look out, one morning in January,

To find him in his armchair, in the yard.

It had snowed all night. There was a drift

As far as his chin, like an alb.

'Come in, my child. Come in, and bolt

The door behind you, for there's an awful draught.' (14)

The dramatic reversal of perspectives is buttressed by the relocation of point of view and by the change in poetic diction from description to a more enunciatory mode. Evidently, the retired minister has now also taken leave of his senses; he has reached a state of senility after a life of repletion, a commonplace conclusion to a natural life cycle. Conversely, repercussions of remorse for his act of apostasy have finally undermined his sanity. Almost seated on a throne, metaphorically dressed in pontificals and echoing Christ's words to the little children, the apostate finally finds himself close to the interior, the vestments and the supernatural solitude from which he once absconded. In many aspects, a twin brother to Joyce's Father Flynn, 'The Bishop' becomes another representative figure of the inescapable, ambivalent forces of religion. In the whiteness and frigidity of these verses, 'alb' appears astonishingly apposite. The contradistinction of this word for white-coloured ecclesiastic attire from the word for a summit of inclement climate - alp -depends solely on the minimal difference of that word's final sign - the voicing of the final utterance designates the textile insignia of religious service; the unvoiced variant connotes a remote place of cold, solitude and silence. Subtle, sublime and subliminal, 'alb' inflects the bishop's fate.

Conception, birth, religion: big questions about identity and destiny surround the central mystery of Brownlee's disappearance, always in a language that doubts, derails and differentiates itself, and that challenges incessantly its own procedures. It appears natural that the issues of nation and nationalism are also part of Brownlee's dilemma, as are the grand narratives of identity and belonging, identification and becoming. To treat such a grand theme of nation and nationalism in twenty-six-word, as 'Ireland' does, succeeds in paring down great ideas, not without irony and sarcasm, to a manageable format. Certainly, this minimalism includes an exquisite feat of language condensation in which 
Muldoon often excels and posits the rhetorical question or challenge as to how much can you actually retain of large discourses in the minutest form?

The Volkswagen parked in the gap,

But gently ticking over.

You wonder if it's lovers

And not men hurrying back

Across two fields and a river. (19)

The covert rhymes in this imagist mystery convey a clandestine atmosphere and the trimetrical tick-tack indicates triple valences and functions as an ominous count-down. Do the two incognitos have a deadline to meet and will they make it? Do they flee from a ticking bomb, from a jealous third partner, from the police or the army? Perhaps they are just friends in a fluster or lovers on a quick errand? A really worrying aspect of this poem is its disclosing of a place where love and terror cannot be easily distinguished. For whatever reasons the fugitives are running, although we don't know from whence they came or to where they go; as representatives of Ireland they present their nation via ideas of uncertainty, plurality, mobility and unknown identities. Thus, the disconcerting scene not only confirms Ireland as a place of constant terror, it also shatters principles of blinkered conviction and established identity processes and leaves several questions unanswered. These include: what nation do the fleeting figures actually represent? Is Ireland a place they escape from or to? Why?

Uneven terrain and natural obstacles in the poem, 'the gap, two fields and a river,' indicate that Ireland is not as much of a unity as the title indicates. Syntactically, this convolution between unity and division is rendered by clauses in the sentence with the poem's unconventional form suggesting that Ireland is not easily defined. The image of Ireland as a Volkswagen with an idling engine appears as an alternative to many ideological conception of nationhood. The Volkswagen is placed in a dip, possibly between Ireland and Northern Ireland. Muldoon's poem is also positioned between and beyond two blocs of thought and poetic representation. The radical impetus of the poem becomes even clearer when read in relation to Tom Clyde's assessment of poetry in Northern Ireland in the 1980s, and his prescriptions for the future:

You will search in vain in recent volumes for anything which speaks to the contemporary statelet, the Ulster of both BMW and Volvo's busiest British dealers. ... Perhaps one solution could be a rejection of romanticism, which is the ethos embraced most fervently on all sides, in 
favour of a new modernism with its traditional concerns for alienation, psychological realism and relativism adapted to our needs. ${ }^{17}$

Muldoon's poem attends to the relative status and juxtaposed complexities, of not only Northern Ireland but also Ireland, with an image that even steers away from the partitioned polarity of poetics and nations inherent in Clyde's assertion. As a popular means of transportation from German assembly lines, the import of the Volkswagen - a bug and a beetle in most poetic and political discourses - bustles with exactly the commerce, consumerism and modernism that Clyde sees as lacking in current accounts of the province. It captures the industrial production that Northern Ireland historically shared with German centres of industry, but ambivalently so, as the Volkswagen obviously comes with some contentious associations of conflict during the two world wars. Similarly, the Volkswagen evokes reminders of politico-ideological traffic between Ireland and Germany during the wars, and raises questions of economic in/dependence. Out of gear and with a low rate of revolutions, the static motor echoes pre-Celtic Tiger industrial unproductivity, a sense of stasis emphasised by the verbal passiveness of the poem's indolent first sentence. Ultimately, the Volkswagen overrides neo-Kantian idealism, one of the primary sources of Romanticism, in a symbolic updating of ideas and idiom. Muldoon's poem includes much of the alienation, realism and relativism of Clyde's critique, but these modernist maxims are placed on the borders of national discourses and indiscriminate internationalism. Although discourses of nationality, irredentism and loyalism - other reasons for Brownlee's fate - are registered in the poem, Muldoon's mechanical metaphor (which, by the bye, takes his enduring horse power for a technological ride), his defamiliarised form and his syntactic solutions render redundant the mythological reproduction of nationhood, anthropomorphic figuration and the binary poetics of organicism and modernism in much poetry at the time. 'Ireland,' in a single complex sentence, revs up conventional metaphors of the nation, overtakes romanticist traffic and crashes full force into larger discourses of ideological production. 'Ireland' is alterrative.

Some of the borders, divisions and demarcations implicit in 'Ireland' become explicit in 'The Boundary Commission.' The title, contentious in itself, refers to the 1921-25 border negotiations in the aftermath of the AngloIrish Agreement and the Civil War and the continuous reviewing of constituencies in Northern Ireland, with all the connotations of border campaigns,

17 Tom Clyde, 'An Ulster Twilight? Poetry in the North of Ireland,' Krino, no. 5 (1998), 100-101. 
gerrymandering and sectarian slogans. Two quatrains with italicised and plain fonts add configurative clout and tension to this delineation of the negative outcomes of partition. The first three italicised lines, which connect the poem to the sense of randomness in the first italicised edition of New Weather, destabilises the poem's own discourse. This distinguishing of verses by graphic design inscribes the poem with internal borders and visualises a sense of separation. That only three of the lines in the first quatrain are separated by this technique induces a sense of manipulation and mismatch. Besides, italicised text feigns authority, suggests citation, indicates quotation, and places the poem between fact and fiction. In the poem, the border runs down the centre street of a village to place the butcher and the baker in separate states, an invisible barrier that also subjugates the course of nature:

a shower of rain

Had stopped so clearly across Golightly's lane It might have been a wall of glass

That had toppled over. He stood there, for ages,

To wonder which side, if any, he should be on. (15)

The syntactic continuance of the sentence across the stanzas suggests a sense of continuity and congruence across the divide caused by the border in closeknit communities. The stopping short of natural phenomena, such as the rain, reveals the preternatural division of the superimposed border, and conceptualises the many territorial, political, denominational, familial and psychological confrontations of border districts. Neutrality or a middle stance is no option. Any position of doubt and remonstration is subsumed by a totalizing binarism and the dispelling of these strictures seems to remain beyond individual control. Neither does any traffic or exchange between the two domains, if that is possible, seem to entail anything but futility: imagery of broken glass evokes breakage and destruction. Uncertainty, reflected in the plasticity of the third person pronouns; disintegration, seen in the second stanza's dissolution of the first stanza's half rhymes; and paralysis, captured by a series of clauses, are the outcome of this detrimental division. Some of this despair is alleviated by the sense of balance in the poem; it does not take sides. Division is made clear, but the binocularity of this border vision transcends sectarian insularity of two implacable domains in its balanced tone; even the balanced distribution of two quatrains ensures equilibrium. An unflinching will to non-commitment, despite its apparent impossibility, also serves to refure and surpass the present state. Such a conviction of impartiality pertains to the negotiations of poetic 
positions too. In attitude and imagery 'The Boundary Commission,' another constraint upon Brownlee's situation, illustrates the apoliticality that Heaney criticises in Muldoon's poetry, and how this balance of oppositions is mediated by linguistic and syntactic strategies. ${ }^{18}$

Two portrayals of agrarian communities, tradition and nationhood, 'Early Warning' and 'Lull', attend to rural life organised around the schism presented so forcefully in 'The Boundary Commission.' In this context, the two poems also echo the divisions of Heaney's 'The Other Side' in Wintering Out. 'Early Warning' juxtaposes the different reactions of two individuals to the warning on the wireless of apple-scab disease. The persona's father immediately sprays the apples; the other, 'our Protestant neighbour Billy Wetherall,' 'Would sling his hammock / Between two sturdy Grenadiers / And work through the latest Marvel comic' (16). In all its linguistic potency, the poem does not wince from using stereotypes whereby the Protestant dependence on military support is rendered colloquial ('grenadiers,' obsolete for pomegranate trees, rings with the colloquial term for the British Army's first regiment of household infantry) and Catholic belief in marvels is ridiculed. Yet the poem also goes against this grain of stereotyping: Protestant laziness undermines the Protestant work ethos as defined by Weber and any Catholic sense of divine design is countered by hard work and dependence on the rational remedy of insecticide. ${ }^{19} \mathrm{Omi}-$ nously, the title tends to be laden with other admonitions too, and the word 'lee' in the poem, 'in its modest lee' (16), implicates Brownlee in these borders of agricultural practise and discourses.

Its counterpiece, 'Lull,' corresponds to 'Early Warning' in its focus on temporality and an agrarian community with ingrained attitudes. The title word's alphabetic construction, syntactic undecidability and semantic duplicity contain, astoundingly, a fissured whole as the three ls embrace the u protectively in this biliteral unity. Stasis and activity, simultaneously, assert the word's status as both noun and verb. Idioms of nature - the lull before the storm, the

18 In his discussion of commitment and critique of deconstructive tendencies in 'The Prenatal Mountain: Vision and Irony in Recent Irish Poetry,' Heaney upbraids Muldoon 'whose swerves away from any form of poker-faced solidarity with the political programs of the Northern Catholic minority (from which he hails) have kept him so much on his poetic toes that he has practically achieved the poetic equivalent of walking on air'. Seamus Heaney, The Place of Writing (Atlanta: Scholars Press, 1989), $5^{2}$.

19 Max Weber, The Protestant Ethic and the Spirit of Capitalism, trans. Talcott Parsons (New York: Charles Scribner's Sons, [1904-5] 1958). Weber's influential analysis has been disputed, but perhaps not entirely refuted. See also Thomas Mann's Nobel-winning novel Buddenbrooks (1924) which, in its critique of philistinism, also charts the decline of the aristocratic family through a dissociation of their capitalist business from a protestant ethic. 
storm lulled - provide parallel association in a relaxation of vigilance or temporary pause in human activity. In form, this sonnet of smouldering tension suspends the traditional divisions of its own genre in the elision of turning point and in the continuance of theme throughout the verses. Remarkable dulcet assonance and mellifluous sibilants bestow peace and harmony and the evenly-balanced distribution of strong and weak rhymes adds symbolic equipoise. Deibhidhe effects strengthen Gaelic heritage, just as the colloquial idiom and relaxed metrics mirror the demotics and down to earth mentality of the Troubles: 'I've heard it argued in some quarters / That in Armagh...' (17). Northern Ireland is the obvious epicentre and 'Armagh' links this poem to the previous apocalyptic 'Armageddon, Armageddon.' Beautiful and beguiling, the Home counties, Christmas, familiar gospel and the comfort of the hearth exude a benevolent atmosphere of everyday pleasantness. Its stanzaic division of four semantic fields hints of a larger Irish dimension, as much as the tercets suggest internal trilateral relations: Holy Trinity, Ireland - Northern-Ireland England, Dantean verse form. The poem, however, starts with a line of dispute and veiled divisions in one of the most contested counties during the Troubles: 'I've heard it argued in some quarters / That in Armagh they mow the hay / With only one week to go to Christmas' (17). The apparently carefree rhetoric conceals a potential drastic turn to diehard and long-term devotional perspectives: 'Tomorrow is another day' (17). A smouldering sense of fomenting unrest underlies the apparent tranquility of the domestic scene and the seasonal peace its tranquility seems to represent: 'There are still houses where the fire / Hasn't gone out in a century' (17). Keeping the fire lit in a safe house while wintering in symbolises luminously the nurturing of patriotic passion in anticipation of a better season for outdoor work and agitation, more grimly understood to include arson and incitement to violence - an intermittent cessation of action called by the title and reinforced by the final three lines' lacunae of timelessness and lassitude: 'I know that eternal interim; / I think I know what they are waiting for / In Tyrone, Fermanagh, Down and Antrim' (17). Written at a time of failed ceasefires and political stalemate, the poem records contemporary deadlock, but also harks back to centuries of cyclical violence. The cynical evocation of the pernicious reality of the 'Lull' as a temporary ceasfire in a centuries-old conflict presents us with a grimly pessimistic recognition or concession to a view of the Anglo-Irish conflict as immutable and insoluble. Manmade conflict and spasmodic violence are seen as natural and inevitable phenomena. A critique can be construed from this portrayal of lackadaisical ineluctability. Both biblical millenarianism and political utopianism focus beyond the immediate matters and the incumbent reality of the existing order, and contribute ideologically to an endless deferral that only perpetuates the 
inadequacies of the present impasse. Such a critique puts both sides of the divide under scrutiny and criticises them with equal force. A divided society in which both sides maintain a statics schismogenesis suggests other reasons for Brownlee's immersion or emigration. Titles, syntax and lineation in 'Early Warning' and 'Lull' articulate separate agrarian traditions, which also add motivation to Browlee's disappearance.

Powers of religion, nation, and bifurcated traditions mould the unfolding of self, as do the institutions and processes of education. In the ten half-rhymed couplets of 'The Geography Lesson,' the seasonal importation of goods from exotic corners of the world shadows the situation and possible futures of the pupils. Boxed in by the classroom, the children are 'small and wild // Against a map of the known world, / The back row of the class of '61. / Internal exiles at thirteen or fourteen' (10). The number of stanzas account for the pupils' (and Muldoon's) age and the couplets configure alternative lives and unacknowledged drives; the 'unremembering darkness, an unsteady hold' (10). Stanzaic transition and lineation, most strikingly the last verbless and full-stopped subordinate clause, impose isolation, stasis, and impasse upon the upcoming generation. In 'The Weepies' (11), the fascinating world of film provides (the same) young malleable minds with a medium of emotional self-enhancement. 'Cuba'(13) offers a lecture on moralism in its juxtaposition of 'the world at war' and juvenile courting. Laconic lessons of lewdness expand the curriculum vitae in 'Bran' (12). The most frightening lesson before Brownlee's disappearance, however, seems to be the one taught and learnt from 'Anseo.'

'Anseo' highlights the centrality of language in its very title. The word offers a linguistic alternative to English. It stirs incomprehension and mystery to non-Gaelic speakers and it offers the familiarity of the commonplace to those who understand the language. Its sense of secrecy and shibboleth gets to the heart of the matter. Gaelic for 'here and now / All present and correct' (20), the standard roll call for school attendance carries wider implications of duties and proprieties; questions of freedom and fate are inextricably interwoven, pronominally and personally. 'Anseo,' 'the first word of Irish I spoke' initiates the persona into another language, and another course of life. The call remains unanswered in the absence of Joseph Mary Plunkett Ward, an unexceptionally inauspicious name. 'Joseph, Mary and Jesus,' one might say, and somewhat cursed from the beginning, the name also evokes the fate of its namesake, Joseph Mary Plunkett, the Irish nationalist poet and leader of the 1916 Easter Rising who was afterwards executed. Ward, of course, also evokes numerous ideas of guardianship and custody and this heavily-allusive epithet, Joseph Mary Plunkett, literally initialises his own sado-masochistic self-assertion by engraving the letters of his name on the stick with which he is to be punished 
for his absence. His formidable resistance to and endurance of the Prussian discipline and corporal punishment of the school system finally leads him to a reiteration of the same coercive structures as commandant of an IRA unit: 'His volunteers would call back Anseo / And raise their hands / As their names occurred' (21). Now answering to the name Joe Ward, the diminutive inscribes a departure from but also a reduction of personality. This sinister poem indicts totalitarian elements in education and liberation ideology, as the three stanzas reveal the inherently suppressive elements of an institution of enlightenment and a regiment of emancipatory idealism. However, the devotion to these pedagogic and patriotic orders by the schoolmaster and the 'Quartermaster' is copper-fastened by sonnet form. In view of these systems of draconian discipline and coercive strictures, the volume's elevation of whims and whimsicality make sense. ${ }^{20}$

In his pride, punishment and discipline, the protagonist's fated resistance also represents tendencies in hermeneutics and literary theory. If a poem is meant to answer back to external pressures and artistic demands, Joe Ward's upright confrontation and subsequent deviation mimic Muldoon's premeditated non-compliance and forging of his own, frequently controversial, poetic register and imaginative idiom. Ward's defection from school and his rise in rank reflect metaphorically Muldoon's resistance to and departure from the many schools of literary criticism to which he has been subjected, and the aspirations and anxieties he exerts upon new talents - a double stance familiar from 'Lunch with Pancho Villa' ( $M, 11-13)$. Simultaneously, in its double focus, the poem's observing persona hints of another Muldoon, the informed witness who withholds judgmental evaluation.

'Anseo' appears as the last pugnacious depiction of the many individual dispositions and public conditions that might have provoked Brownlee's disappearance and it brackets, together with 'Immrama', his vanishing points of auto-asphyxiation or egregious emigration within two entirely Irish idioms. Sonnet form and a doubled sense of departure and arrival further connect this central triptych. If, up to this point, Why Brownlee Left reads as a combination of bildung poetics and Gramscian critique of cultural hegemony, the subsequent sequence indicates extraordinarily imaginative departures, frequently unresolved or verging on death - perhaps just another threshold - in a language which often unfolds from its own traditions and meaning. 'Immrama,' is such a poem.

20 Joseph Mary Plunkett appears again, alongside Oliver Cromwell, in 'The Firing Squad' (оTTWK, 81). 
'Immrama,' Gaelic for voyages, alludes to the great travelogues across the seas to the Otherworld in Irish mythology. Its impetus is clearly linguistic and narrative. In form and idiom, the colloquial sonnet departs from the travel epic. Still, these verses trail, not the genealogy or biography, but the spirit of the persona's father, and opens out on truths that are told through narrative events that may not necessarily have taken place. The poem is a specimen alterrative in its integration of alterity into language, storytelling and thinking, and in its delineations of alternative life possibilities. The son's trailing of his vagrant father's spirit through somewhat familiar conditions of disease and deprivation ends at a building site from which his father bolted, only to reappear mysteriously in Brazil: 'That's him on the verandah, drinking rum / With a man who might be a Nazi, / His children asleep under the mosquito-nets' (23). This apparition gives a gloomy, historical twist to Brownlee's past and future. Whereas the persona imagines paternal death in 'The Waking Father' ( $N W 10)$, the questing child here conjures up another life and family of the father, perhaps at the cost of his own existence. Enmeshing the father in a milieu of German war criminals, the vision is almost surgically detached from familial sentiments and habitual affinities. Negative in all its aspects, the ability to develop alternative lives for your own parentage, or to postulate your own nonexistence, creates a space for unlimited fantasy beyond the closures of (auto-) biography and history - a striking alterrative.

Just as 'Anseo' and 'Why Brownlee Left' reflect upon the positions of poetry and poet in their themes and language, 'Immrama' also dwells upon its own self-generative non-veracity by similar means. In the atmosphere of totalitarian ideology and alternative families, the first line in this sonnet, 'I, too, have trailed my father's spirit' (23), assumes all the anxiety of influence. This anxiety includes Muldoon's dedication 'for my Fathers and Mothers' in New Weather, his own previous father poem 'The Waking Father' in New Weather and the many more to come: 'Immram' in this volume, 'The Mirror,' 'My Father and I and Billy Two Rivers' and 'Cherish the Ladies' in Quoof; all of Meeting the British which is dedicated to his father; 'Third Epistle to Timothy' and 'The Bangle (Slight Return)' in Hay; 'Moryson's Fancy' in Maggot and 'Charles Émile Jacque: Poultry Among Trees' in One Thousand Things Worth Knowing. Beyond this catalogue of commemoration, his palimpsests of paternity extend to what Kendall has so fittingly termed Muldoon's 'polycentric pedigree, ${ }^{21}$ which includes, of course, among others, 'Il Duce of Drumcliff,' as Muldoon labels Yeats in 'Yarrow' $(A C, 145)$, Joyce, Frost, MacNeice, Longley, Heaney, and the many bardic

\footnotetext{
21 Kendall, Paul Muldoon, 33.
} 
poets and anonymous authors of Gaelic immrama associated with this volume, to mention just the most obvious creative ancestry.

The quest for the father in 'Immrama' ends in Brazil. This is no accident. This destination reorients totally the ordinary routes of Irish emigration and it incorporates the mythic utopia of Gaelic folklore, Hy-Breasil. The inclusion of fantasy, in this case dark and disturbing, in the personal and the public spirit of the Irish Atlantis overlaps with Seán Hillen's spectacular Irelantis. ${ }^{22}$ In Muldoon's poem, as in Hillen's hyperreal photo collages, fabulation is part of reality. These permutations and conflations anticipate 'Brazil' in Annals of Chile, and mark the true unreality of life - the unrestricted possibilities of what might have been and what might yet be - which can often best be imagined in poetic language. 'Immrama' speculates upon the spiritual pedigree and the unrealised lives of Brownlee, with all their metaphoric implications, by altering the compositions of traditional narrative and by tracing bilingualism. 'Immrama' alters Brownlee, Why Brownlee Left, the reader and much of the poetry and traditional ways of thinking at the time of its publication, and perhaps even today.

Adlinguistic language that explores its own etymology, syntax, grammar and poetic composition coalesces with the volume's mysteries of disappearance, origin and identity or, perhaps, rather, the dissolution of origins or the conceptualisations they entail. Like the tracing of a word's meaning that ends in spurious heritage and doubtful dissemination, quoof for example, and like the searching for stability in a structure that shifts continuously, the poems in this volume substitute ruptures and redoubling for fixity and presence, identification for identity and becoming for being in the questions of life and living, believing and belonging. However much such critical questioning of central principles of metaphysics now appears part of daily discourse, such inquiry into dominant structures of thinking still retains some of its radical force, and traces its own provocative power in communities in the 198 os when the unfolding of individual life was so strongly conceived in terms of undifferentiated ideologies, particularly in Northern Ireland.

'Promises, Promises,' like the tracing of a trail of smoke to its source in a smoky room while the cigarette disappears or is already gone, allows for a complex self who realises his own future by realigning it to a past that is split, spliced and spurious. Past and future possibilities fleet across the page in the contemplative confusion of 'Promises, Promises,' which sounds resigned, resigned in its laconic iteration of optimistic vows. In this sonnet triptych, a grass-inebriated persona in the tobacco-land of North Carolina - 'There is such 
splendour in the grass / I might be the picture of happiness' (24) - indulges in reveries of reunion with an abandoned lover. Disappointments with grass and landscape, possibly reminiscences from elsewhere, bode ill for amorous fidelity and solemn engagements: 'Whatever is passing me by is passing me by' (24). In cadences that capture the ruptures and redoubling of a becoming self, two semi-repetitive sonnets are prised apart by a retrospective reminder, a poetic construction which configures formally a liminal state of doubt and double binds, and supplant any clear-cut choice of separation or reunion. The interpolated sonnet harks back to Raleigh's Roanoke settlement, the disappearance of which is still today a mystery, and the persona's oneiric identification with one of the early settlers - 'I am with Raleigh, near the Atlantic' - implies that he might be a descendant of the vanished colonists, in which case his own history cannot be tracked to origins, only traced to lost traces. The disappearance of the colony imbricates the lover's predicament in a larger fabric of conflict and failure - a familiar constellation in the volume and at this stage of Muldoon's oeuvre - but more importantly, enmeshes the absconder's situation in questions of ancestry and progeny. Intoxicating fumes and symbolic trails of smoke surround questions of origin: while the trails, if possible, are traced, the source disappears during the tracing, or was already lost a long time ago. If Raleigh's colony of men dispersed into the native population, as the verses intimate, the association bears the possibility that the lover will assimilate accordingly, and that the woman left behind in 'her room in Bayswater' (25) carries a woman's secret and might be pregnant without her partner's knowledge. Brownlee, if this is him and not somebody else - his father, Muldoon, an analogy for anybody, parts of all of us - has certainly ploughed some new fields, in a Byronic fashion, since he bolted on a whim from his own plot.

The verses trace and track their own lines, too. 'I am,' 'I am,' 'I am,' all three stanzas start, as an Oedipal and futile determination to establish identity and presence over flux and contingency. In phrasing and confused inbetweenness, the three stanzonnets resound with the melancholy of exilic fissure found in Yeats's 'I am of Ireland,' and beyond those verses, 'The Alphabet Calendar of Amergin,' the second poem of the supposedly first poet of Ireland. The paramnesic interlude reverts to the Renaissance history and literature of Sir Walter Raleigh. An account of the lost colony at Roanoke and of Raleigh's prison poem 'The Passionate Man's Pilgrimage,' from which Muldoon quotes three verses almost verbatim, exerts a complex English anxiety upon the poem, an ambivalent anxiety of Englishness that includes the American and the Whitmanesque, as the importance of grass makes clear. Written while on trial for treason pending beheading, the interpolation of Raleigh's lines entangles Muldoon's verses with differentiated views of the colonial conquest and 
plantation policies of Ireland by England during the Renaissance. In this poetic context, and contest, Muldoon's poem redoubles Heaney's recourse to Raleigh's life and lines in 'Ocean's Love to Ireland' in North, another poetic triumvirate. Where Heaney, in that poem, surrenders problems of individual identity to concepts of nation, and re-enacts Raleigh's poetics and politics for overt corroboration of stereotypical ideas of colonial rape and violent suppression of people, land and language, Muldoon confronts this idiom with continental displacement, multiple literary lineage and insoluble questions of identity. In Muldoon's own work, these traces disappear and reappear and mysteries of the failed colony become central to the many secrets, riddles and unresolved projects in Madoc. 'Promises, Promises' integrates aspects of anteriority and alternatives in varying scenarios of what might have been and counter-factual becomings.

The adlinguisticism, intertextuality and alterratives of lost love and lost origins on the American continent in 'Promises, Promises' mirror the mystery of Brownlee's disappearance, and anticipate themes of exit and entombment in verses to come. A succession of seven love poems, as desolate and desultory as the first 'Whim,' follows. Detached, deviant and distanced, these intersecting love poems - 'Truce, 'History,' 'Palm Sunday,' 'The Avenue, 'Something of a Departure,' 'Holy Thursday,' 'Making the Move' - are encoded in the grander narratives of religion, war and history by reciprocal recursivity. Each of the titles designated to serve as a heading to the poem and love theme of the individual poems is itself partly or wholly derived from the thematic contortions to be developed in those very poems. Thus, the titles result as much from the poems as the poems from the titles; the verses define anew the grand terms from which they derive: 'Truce' becomes as chancy and fickle as a one-night stand, and 'History' as personal as sex; 'Palm Sunday' is defined by ordinary days of historical warfare and everyday violence as much the celebrations of Passover; 'Avenue' is mapped on temporal and emotional distance; 'Departure' depends on deviancy and deliverance; 'Holy Thursday' results from a solitary restaurant interlude. Definitions do not depend on what they define, nor does what is being defined depend only upon their definitions; this linguistic redoubling questions how these particular formations of meaning have erased their own coming into being. Such linguistic rupturing bears heavily down upon processes of identity formation by recovering the absent and ignored, by revealing the alterior and the alternative, and by releasing the energies of dissemination. Motions and mutations of this kind require and result from 'Making the Move,' the final recursion in this series of lovely linguistic variations. Certainly, this title anticipates the themes of separation and departure, of emotional flux and future uncertainties, but the inconstancy which moves in the syntactical slide 
of subjects and the vacillation of verbal tense and mood in these verses - all the linguistic features of these lyrical lines which Eamon Grennan dwells on and defines as a masterful characteristic of Muldoon's work - preconditions its own title and delivers the recursivity of the previous poems. ${ }^{23}$ The poem's title and ten reverberative couplets connect these lines with 'The Geography Lesson,' while the prevailing spirit of Homer's Odyssey slots into the unsettling language of the book. The poem also traces the volume's literary lines 'Past bad Lord Byron, Raymond Chandler, / Howard Hughes; The Hidden Years' (32). In a language defined by the problems of love and separation it depicts, this series relates to the possible backdrop of Brownlee's disappearance, as much as the subsequent sequence relates to his possible internment. Language, like love and history, is a battlefield where alternatives always vie for position.

'Were I embarking,' the final line of 'Making the Move' starts, with all the irresolutions of the conditional and the conjunctive. It rings with the stasis and the sense of internment that also surround the mysteries of Brownlee, and the themes of the book. Stifling forces stalk the volume as much as drives of escape and release in a language that creates these dilemmas, and is recreated by them. A cluster of three poems weighs in on the bleakness of death and disintegration. The importance Muldoon assigns to liminality, death and Joyce's 'The Dead' in To Ireland, I governs these desolate figurations and they appear as ultimate termini beyond further dissolution, and functions also as memento mori. Máirtín Ó Cadhain's Cré na Cille also seems to reign over these subterranean conversations. 'A frenzy of maggots / Make short work of so much blood and guts' (34) in the grotesqueries of 'Grief.' And these three poems are entirely selfabsorbed; they would have little life without the many texts, titles and genres which they lean against. 'Come into my Parlour' offers a spectrum of ancestral intertextual voices. Connected to the Victorian nursery rhyme and to Heaney's replay of the Republican song in 'Come to the Bower' in North, Muldoon's poem counteracts the reverence of Victorian children's rhymes and the stance of Heaney's poem, and aligns itself, with Gothic grimness and Hamletian humour, to Grey's eulogy for the unremembered dead, 'Elegy Written in a Country Churchyard.' The third poem in this churchyard suite, 'The Princess and the Pea,' shrieks with haunted voices resonant with a vital adlinguisticism.

'Who is that on my grave?' an anonymous poet of the dispossessed asks in his dialogue of the living and the dead and Muldoon responds grimly, with echoes of Yeats's Crazy Jane, - 'All find safety in the tomb' - in his horrific

23 Eamonn Grennan, 'Two-Part Invention: Reading into Durcan and Muldoon,' in New Irish Writing, ed. James D. Brophy and Eamonn Grennan (Boston: Iona College Press, 1989), 203-232. 
subterranean admixture of fairy tale and romance. ${ }^{24}$ No fairy tale, 'The Princess and the Pea' is rather a gruesome picture of claustrophobia and a paranoiac projection of jealousy. The zestful keen of promiscuous infidelities renders palpable a horrific funeral of the dead and the living, with forceful feminine volition:

This is the dream of her older sister,

Who is stretched on the open grave

Of all the men she has known.

Far down, something niggles. The stir

Of someone still alive.

Then a cry, far down. It is your own. (33)

As the first line of both this and the first stanza makes clear, this is not an aisling in which the spéirbhean - the sky woman and traditional female representation of Ireland since the poems of the dispossessed - bemoans its fallen status to the poet; this is a different lament by an older relative. This bereavement concerns dead lovers, not dispossessed poets and planters. The poem pits the erotic against the platonic, the personal against the political, the bereft against the unsettled. Any sacrificial myth of the numinous motherland, Frazerian, Heneayesque or other, is occluded, but the poem maintains its energies by intertextual reference within the Muldoon canon. Its gothic elements recall the agoraphobic refugee of 'Vampire' in New Weather, point forward to paternal commemoration in 'The Mirror' in the following Quoof, and, of course, insert another installment in this volume's mystery: Brownlee might be one of the corpses in the grave. Whoever the dead and the living might be, the graveyard image illustrates most graphically canonical suffocation of the individual talent. The stifling burden of deceased poets upon the living writer severs him from his mundane muse and the life of the world above, and threatens to asphyxiate him. Conversely, the macabre situation illustrates how the artistic gestures of a vigorous new poet alter the positions of the predecessors who weigh him down, and how he inserts new life into dead language. Dislocated, the cry from below could also be the woman's; parts of her were buried with her beloved. The woman's desperate embrace of passed loves also evokes the painful liberation of contemporary female poets - Eavan Boland, Medbh McGuckian, Nuala Ní Dhomhnaill, Eiléan Ní Chuillenaín, Paula Meehan from their patriarchal tradition, or Edna Longley's protest against the misogynist

24 Seán Ó Tuama and Thomas Kinsella, eds., An Duanare 16oo-19oo: Poems of the Dispossessed (Dublin: Dolmen Press, 1981), 313. 
burial of women poets, women editors, feminine attitudes and female perspectives in Deane's Field Day Anthology. ${ }^{25}$ The dispassionate final twist - 'It is your own' - ensures that no reader of these lines escapes their pallid embrace. Nor does the poem escape the symbolic weight and phonetic possibilities of its own title.

A streaming of royal candidates according to their hypersensitivity, as in the fairy tale to which the title refers, is transposed easily to a selection of artistic superiority on the basis of an exquisite sensibility. There is contention here, between the two sisters, and between all the double divisions in the poem: the title's bifurcation, the two stanzas, the younger and the older sister, romance and reality, the living and the dead, views from the top and the bottom in the grave. The title's paradoxical combination of human nobility in the guise of the princess and 'the low' or everyday produce, the pea, contains a literal figuration of commendable idiomatic solemnity versus much condemned semiotic freeplay. Connected by the alliterative ps, a regal and predominantly monological word is juxtaposed with a polymorphic one. Peas and pi, two phonetic siblings, bring in associations of infinity that suit this poem on death and posterity. Pea, an obsolete exclamation of contempt - pooh - also sounds akin to the act of urination to suggest a latent paroxysm of hatred and contempt; to piss on the grave of everything passed. Pea is also a regional American term for the sliding weight of a safety-valve; Muldoon minds his Ps and Qs. The dehiscent word itself, like the two sisters, and the poem's many doubles as well as the frequent minimal differences in Muldoon's poetry, are not as like as two peas. They are pees in the terminological sense of mining and currency, the portion common to two intersecting veins, or the decimal values in a larger system of currency flows. The many lives of the pea in 'The Princess and the Pea,' alongside the intertextual vitality of these death poems, are ablaze with all the hermeneutic wildfire that Muldoon's poetic language so often engenders.

Muldoon's poetic language is never straightforward: it combines and defers, it dissolves and dissimulates, it always exists upon its own text and context. 'I Remember Sir Alfred' displays these qualities, and maps the conscious composition of creative writing. The reference made in the title to the great construction and road building company raises high entrepreneurial invention, engineering and industry to the plane of metaphor for poetic artifice and the building of creative edifices. Road-building suggests a turn away from organicist models of poetic creativity; the poem suggests mathematical calculation, methodological application and industrial production as an alternative way of thinking poetry. Yet the lines are confused by the 'singleminded swervings'

25 Longley, The Living Stream: Literature and Revisionism in Ireland, 22-44. 
(18) of Sir Alfred's dislodged hare. Although these verses pave the way for the Volkswagen in 'Ireland' and the many commemorations of Irish navvies in Moy Sand and Gravel, their 'swervings' cannot be easily contained by the scientific imagery of the poem. Title and hare link the poem to Yeats's 'Memory' and associations of road construction swerve to Frost's 'The Road not Taken,' whereas the nonlinear and unpredictable 'leaps and bounds' (18) of the hare enact Irish whimsicality and Byronic whims: Bloomian ideas of anxiety underlie lines and swervings.

Swervings, lineal constructions, intertextual byroads and linguistic detours all of these alternatives to the straight and the narrow revolve themselves in the solemn hilarity of the final tour-de-force, 'Immram.' This poem, like the earlier 'Immrama,' references and redoubles the topography of quest literature. Quest literature offers a pertinent point of departure for the poem's and the volume's critical engagement with prevailing ideas of origins, ancestry and identity, both in a personal and poetic sense, and in the many interrelations between them. In itself a fabulous journey of departures, the impulsive quest for origins in an American metropolis proposes a way out of the sexual stalemate in Belfast's Botanic Gardens in the opening, a twinning of the previous 'Immrama,' and a possible solution to the riddle of Brownlee's disappearance. Parts of the poem's many dis-courses can be traced to the opening 'Whim.' That title and poem point to the caprice of the volume, a possible reason for Brownlee's abrupt departure, and to the whimsies of 'Immram.' Whims and wonders of unimaginable ingenuity subsume the volume's aberrant voices and visions, and are ghosted by textual precursors. The poem's discursivity and its speed on the highways of literary traffic also connects it to the impulse of the initial 'Whim':

In Beppo (1818) we see Byron at his brilliant best - witty, wise, at one moment stepping on the gas and cruising along the narrative equivalent of a six-lane highway, at the next content to pull over and make a leisurely digression down some back road or blind alley. ${ }^{26}$

Muldoon's description of the narrative propulsion and relaxed whimsicalities in his favourite poem by Byron also seems to set the place and pace of his own capricious night drive:

They came bearing down on me out of nowhere.

A Buick and a Chevrolet.

Muldoon, The Essential Byron, 5 . 
They were heading towards a grand slam.

Salami on rye. I was the salami.

So much for my faith in human nature.

The age of chivalry how are you? (40)

Compressed into a cliché of culinary rawness, the protagonist's position reflects the pressures of idiomatic alternatives, literary predecessors and views of humanity congruent with the author's quest to stake out his own poetic course: 'Immram,' the Gaelic word for voyage, appears as another of Muldoon's subjective correlatives. The pluritextual permutations of Muldoon's mock mini-epic take much of their initial impulse from the old Irish travel myth, Immram Curaig Máele Dúin (Voyage of Máel Dúin's Boat), composed from the many scriptural fragments dating from the eight century onwards, and also known from Tennyson's poem and MacNeice's 1962 radio play, The Mad Islands. Mael Dúin means 'bald head,' and these patrilineal lines in Why Brownlee Left pit hirsute Muldoon against the ancient scribes, against his previous poetic identities, against past and contemporary poetics. In the old version, the hero - Máel Duín, the son of a violent union of a marauding Aran sailor warrior and a nun who was fostered by the nun's sister queen - embarks on a sea journey to avenge the murder of his father. After transgressing the geis, the taboo upon him, he is doomed to oceanic vicissitudes and adventurous island episodes, during which he undergoes spiritual transformation and finally achieves reconciliation with his father's murderers. The violations of taboos by the exilic son of complex origin lead to peace and reconciliation. Muldoon's aesthetic self-identifications are persuasive and plural. An original and powerful aside to the circuits of violence and vengeance in Northern Ireland, and their underlying ideas of origin, ancestry and identity, the poem also demonstrates the creativity of Muldoon's poetic language.

In Muldoon's 'Immram,' the persona is situated in the sordid conditions of urban slums and seedy entertainment venues beyond the boundaries of suburban respectability, just as his outlandish text departs from familiar textual grounds and redefines literary pedigree:

I was fairly and squarely behind the eight

That morning in Foster's pool-hall

When it came to me out of the blue

In the shape of a sixteen-ounce billiard cue

That lent what he said some little weight.

'Your old man was an ass-hole.

That makes an ass-hole out of you.' 
My grand-father hailed from New York State.

My grand-mother was part Cree.

This must be some new strain in my pedigree. (38)

This early morning fisticuffs suggest a new encounter with Muldoon's previous poetry, Celtic heritage, classical genealogy and ancestral inheritance, just as the succeeding narrative series of para-byronic stanzas reveals a humorous play on the quest for home, family and origin. In medias res, the persona is firmly placed at the back of the black having indulged in a proverbial quantity of pints in an ambience that recalls the pool rooms, clubs, licensed premises and the mixed marriages in Mules. 'Foster's pool-hall' catches the triple dilemmas of surrogation, genetic attributes (of the gene pool) and environment, not to mention a popular Australian beer, which all feature in this circuitous and unresolved quest. It also hosts the play with textual forefathers, for example 'bad Lord Byron, Raymond Chandler, Howard Hughes: The Hidden Years' (32), listed in 'Making the Move.' Similarly, the stanzaic revelation stems not from a celestial source, but from the hard facts of verbal statements and corporeal enforcement. The hard-hitting facts in the billiard bar precipitate the persona's quest for his father, but the Foster fosterling's father 'could have been almost anyone.' Never to be found, he was most likely a drugs mule, perhaps on the run or murdered in Argentina or Brazil. The encounter with the top man of the crime pyramid, a Howard Hughes-like troglodyte, provides an absurd conciliation but no dénouement:

'I forgive you,' he croaked. 'And I forget.

On your way out, you can tell that bastard

To bring me a dish of ice-cream.

I want Baskin-Robbins banana-nut ice cream.' (47)

By absolving the visitor for the disappearance of his father - a disappearance he is probably responsible for himself - the nebulous and semi-imbecile godfather confers crime upon the questing son and implicates him in insoluble mystery.

The problematic quest for individual origins also involves foundation myths and communal identification. A police man at the NYPD recounts:

'My father, God rest him, he held this theory

That the Irish, the American Irish,

Were really the thirteenth tribe,

The Israelites of Europe. 
All along, my father believed in fairies

But he might as well have been Jewish.'

His laugh was a slight hiccup.

I guessed that Lieutenant Brendan O'Leary's

Grand-mother's pee was green,

And that was why she had to leave old Skibbereen. (44)

The Chandleresque journey of intoxication, violent encounters and Byronic excess challenges romantic ideas of the Irish diaspora in America by means of Yeatsian quips and venereal bawdiness, while also questioning myths of biblical descent at home. Later in the poem, the narrator leaves the hotel lobby after Mrs. and Mr. Alfred Tennyson, whose exit makes manifest the many waking fathers and mothers in the poem - a celebration of artistic ancestry that also extends to the Queen's University Belfast critic and academic, Michael Allen, to whom the volume is dedicated. The Telemachian search for a father and for origins descends into an wayward and compulsive journey that arrives at its very point of departure. Finally, the son makes his way back, 'like any other pilgrim to Main Street, to Foster's pool-room' (47). Circular and disorientating, the tracing of his father's tracks sends the poem's protagonist back to the beginning, but in the course of the journey a welter of possible fathers and mothers with whom the foundling can identify have been presented.

The poetic language deployed in this quest for origins is contiguous with its numerous deferrals, doublings and dissimulations. Expansive intertextuality discloses lines of familiarity that cannot easily be categorised or terminated. A process of interwoven contingencies and continuities that fosters new lines and identifications unfolds itself. Other linguistic strategies strengthen these transformations. Italicisation, for example, that marvellous trick of the tale in the first edition of New Weather, presents a technique for marking on the linguistic body its own traces. 'Shall We Gather at the River' and 'Bringing in the Sheaves' (38) reference two traditional hymns in the textual whirligig; 'The Lord is my surf-board. I shall not want' (45) substitutes Psalm 23's supplication with Beach Boy californication; 'The Way Of The One Wave' arrives at an unreferenced title. This chain of iteration suggests, not without irony, how even religious discourse contains its own force of change and transformation. And that such language may have an aetiology that is just as whimisical.

'I am telling this exactly as it happened' (38), a snide sentence declares, with claims on truth and representation. Yes, this is the way it all takes place - in the poem; and this poem is part of the real. However much poetic language distinguishes itself from other types of language, it belongs to the real world, no matter how marginal its position might be therein. Self-reflexively though, the 
remark points to the problems of narratology, to how the story is narrated more than to why it is narrated and to what it narrates, but most of all to the non-representational closure of much narratology. Such structuralist structures are splintered from within in 'Immram' by this type of multidiscursive narrativity which points ahead to the multidiscursive 'The More a Man Has The More A Man Wants' in Quoof, to Madoc and to 'The Bangle (Slight Return)' in Hay. Narrative complexity is also reiterated through the poem's cross-generic energies, italicisation and fictional references, and in the sliding semantics of its language. Beyond the poem itself, the narratological strategies of this recursive poetry illuminate previous poems and anticipate later ones. Its Gaelic title is germane to the discussions of Gaelic translations in the foreplay of 'Whim,' a title which is endowed with broader resonance by the whimsicalities of the final poem. Just possibly, the protagonist of the final poem is engendered by the first poem's procreative gambit. 'Immram,' singular for journey, connects with its plural prelude, 'Immrama.' Its textual allusions to previous poems and volumes, as well as anticipations of those to come, are too numerous to mention here. As a redoubling of previous poems, 'Imramm' mimics and reconfigures its own structures and concerns. The initial twenty-seven poem series starts and ends in the Botanic Gardens in Belfast, a structure which is replayed with a variation in the circularity of the final poem embarking from and arriving at 'Foster's pool-hall,' the first and last word of the thirty stanzas. This circular odyssey in the literally double-spaced 'Ithaca, New York' (45) adds significance, presence and detail to the void, absence and disappearance of the mystery at the centre of the book, 'Why Brownlee Left.' The final poem of the book 'Imramm' replays, recentres and redistributes many of the traces of the book. Funny and fascinating, these narrational strategies and deeds of poetic derring-do subscribe to Muldoon's belief 'that poetry can be serious without being solemn, that it might even be fun,' and add up to a counter-discourse in poetics and politics and in other spheres. ${ }^{27}$ Why Brownlee Left dares to rethink the originary and self-identifical and to give credence to such a reconsideration of origins, as being not merely a lamentable loss. This serio-ludic poetics also engages with profound issues of identitarian politics and teleological thinking. Imaginative realisations of self, in a language and form that unhinge themselves, suggest possibilities for the individual to imagine for her- or himself an alternative form of self-realisation untrammelled by the habitual factors of origin, ancestry, history and closed systems of thinking.

The poetic language of Why Brownlee Left brings in its train a number of events upon which parts of the language by which these events unfold is 
predicated. It is a language in which Muldoon appears and disappears as a subject, both a personal and a poetic one. The splitting and splicing of literary sources in a language that incessantly retraces itself allows for an irreducibly complex locomotion to be played out. In the absence of a full appreciation of these strategies, the mystery of the volume cannot be fully understood, nor can a critical account of the multiple alterratives of Why Brownlee Left be given. 